\title{
PELATIHAN ACTIVE CASE FINDING TB PADA PETUGAS SURVEILANS KESEHATAN (GASURKES) PENYAKIT MENULAR
}

\author{
ACTIVE CASE FINDING TB TRAINING ON HEALTH SURVEILLANCE (GASURKES) \\ DISEASES
}

\author{
Sri handayani ${ }^{1}$, Yusthin M. Manglapy ${ }^{2}$, Eti Rimawati ${ }^{3}$ \\ ${ }^{1,2,3}$ Program Studi Kesehatan Masyarakat, Fakultas Kesehatan, Universitas Dian Nuswantoro \\ Jl. Nakula I/5-11, Semarang 50131 \\ Telp. (024) 3517261, Faks. (024) 3569684 \\ yanih61@gmail.com, sri.handayani@dsn.dinus.ac.id
}

\begin{abstract}
Abstrak
Kemampuan mengaplikasikan metode penemuan kasus merupakan kemampuan dasar yang harus dipenuhi oleh tenaga surveilans kesehatan (Gasurkes) dalam melakukan penemuan kasus penyakit menular khususnya TB/HIV. Adapun pelatihan ini bertujuan untuk meningkatkan kemampuan Gasurkes dalam penemuan kasus aktif TB untuk meningkatkan kinerja di lapangan. Metode yang digunakan dalam pelatihan ini adalah aktif partisipatif dimana peserta pelatihan mempraktikan materi yang telah disampaikan. Hasil pelatihan adalah Peningkatan kemampuan tenaga surveilans kesehatan (Gasurkes) untuk menemukan kasus baru TB. Peningkatan kemampuan gasurkes untuk memanfaatkan teknologi sebagai sarana pelaporan kasus TB dalam hal ini adalah GIS. Peningkatan kemampuan gasurkes untuk memanfaatkan teknologi sebagai saran pemetaan kasus TB dalam hal ini adalah GIS. Peningkatan kemampuan gasurkes dalam pengembangan media KIE sebagai sarana mendukung penemuan kasus baru TB.
\end{abstract}

Kata Kunci: Gasurkes, Penyakit Menular, TB, HIV/AIDS, GIS

\begin{abstract}
Ability to perform case finding is a core competency of surveillance team to detect cases of TB/HIV. The training aimed to increases skill of surveillance team to perform case finding of $T B$ active and increases performance in field. Method of the training was active participation where the trainee had to practice in classes. Result of the training was increased of surveillance team skill on performing active case finding of TB. Increased skill of used GIS to report new cases. Increased to use media on supporting active cases finding.
\end{abstract}

Keywords: surveillance team, communicable disease, TB. HIV/AIDS, GIS

\section{PENDAHULUAN}

Berdasarkan data Badan Pusat Statisti (BPS) ada tahun 2016 tercatat jumlah penduduk Kota Semarang sebesar 1.729.428 jiwa yang terdiri dari 848.030 laki-laki dan 881.398, dengan pertumbuhan penduduk 1,66\%. Dari tahun ke tahun kepadatan penduduk kota semarang cenderung naik. ${ }^{1}$

Keadaan sosial budaya tidak dapat dilepaskan dari aspek prasarana yang ada. Pemerintah kota telah melakukan pembangunan infrastruktur disektor pendidikan, kesehatan. Upaya perbaikan sektor kesehatan masyarakat terus dilakuan dengan cara pencegahan dan pemberantasan penyakit menular, pembinaan kesehatan lingkungan pemukiman, penyediaan, dan pengawasan air bersih, penyuluhan kesehatan dan pelayanan KIA serta pemulihan kesehatan. 
Sasaran Pengabdian ini adalah Tenaga Surveilans Kesehatan (GASURKES) Penyakit Menular di kota Semarang. Keberadaan Gasurkes di Kota Semarang merupakan salah satu upaya pemerintah kota dalam penanggulangan penyakit Tuberkulosis dengan melakukan edukasi masyarakat, pendampingan kasus, dan penemuan kasus tuberkulosis. Permasalahan tuberkulosis yang ada dikota semarang adalah: angka kesembuhan dalam kurun waktu 6 (enam) tahun terakhir belum mencapai target nasional dengan rata-rata pencapaian Cure Rate (CR) 63,33 \%, angka konversi pasien TB $69 \%$ masih berada di bawah target nasionnal yaitu $80 \% .^{2}$

Penghambat terbesar dalam upaya pemberantasan penyakit Tuberkulosis yaitu adanya stigma, diskriminasi dan marjinalisasi pasien TB. Sampai sekarang masih ada stigma di masyarakat tentang tuberkulosis, dimana masyarakat beranggapan bahwa tuberkulosis adalah penyakit keturunan, penyakit akibat teluh/guna-guna. Di Semarang TB juga memberi dampak buruk lain secara sosial stigma bahkan di kucilkan masyarakat.

Sekitar $75 \%$ pasien TB adalah kelompok usia produktif secara ekonomi yaitu 15-50 tahun. Diperkirakan seorang pasien TB dewasa akan kehilangan rata-rata waktu kerja 3 - 4 bulan. Hal tersebut berakibat pda kehilangan pendapatan tahunan rumah tangga sekitar 20-30\%. Jika meninggal dunia akibat $\mathrm{Tb}$, maka akan kehilangan pendapatan sekitar 15 tahun. Secara umum, peningkatan kasus TB akan berpengaruh tidak hanya bagi individu penderita dan keluarga tetapi dapat menjadi beban perekonomian pemerintahan kota bahkan menjadi beban negara. Sementara penyebab meningkatnya beban TB antara lain kemiskinan pada berbagai kelompok masyarakat. ${ }^{3}$

Menurut WHO, SIG (Sistem Informasi Geografis) dapat digunakan untuk: menggambarkan dan menentukan distribusi geografis penyakit, analisis trend berdasarkan lokasi dan waktu, distribusi populasi berisiko, stratifikasi faktor risiko, penilaian distribusi sumberdaya, perencanaan dan penentuan intervensi, dan monitoring penyakit. Sedangkan menurut (Soontornpipit2016) manfaat Sistem Informasi Geografis (SIG) dalam bidang kesehatan masyarakat adalah menilai sebaran faktor resiko dan ancaman kesehatan dalam masyarakat, menggambarkan distribusi penyakit dan investigasi wabah, dapat digunakan untuk perencanaan dan implementasi program pelayanan kesehatan, serta sekaligus juga dapat dimanfaatkan untuk evaluasi dan pengawasan program. ${ }^{4}$

SIG adalah alat yang memiliki potensi besar bagi kesehatan karena kesehatan sangat ditentukan oleh faktor lingkungan (termasuk lingkungan sosial budaya dan fisik) yang sangat bervariasi. ${ }^{5}$ SIG memiliki peran penting dalam pengelolaan program pengendalian, pengembangan layanan, dan penelitian pengendalian tuberkulosis. Dalam hal perencanaan pengelolaan, pengawasan pengobatan, sehingga dapat diketahui dinamika transmisi tuberkulosis dan penyebaran MDR TB. ${ }^{6}$ Berdasarkan Uraian tersebut di atas, SIG merupakan salah satu alat bantu yang penting dalam penanggulangan TB, Gasurkes di kota Semarang belum pernah diberikan pembekalan tentang pemanfaatan dan penggunaan GPS dan SIG dalam penanggulangan penyakit TB. Maka perlu diadanya suatu kegiatan pelatihan pemanfaatan teknologi GPS dan SIG dalam penemuan, pemantauan dan pelaporan kasus TB sebagai upaya penanggulangan penyakit TB di kota semarang.

\section{PERUMUSAN MASALAH}

Permasalahan TB di kota semarang (2016) ;

a. Angka konversi TB adalah sebesar $69 \%$, belum mencapai target nasional yaitu sebesar $80 \%$.

b. Angka kesembuhan (Cure Rate) kasus TB adalah sebesar 69\%, belum mencapai target nasional yaitu sebesar $85 \%$

c. Angka Treatment Succes Rate adalah sebesar $83 \%$, belum mencapai target angka nasional yaitu sebesar $90 \%$.

\section{METODE PENELITIAN}

Pengabdian masyarakat ini akan dilaksanakan dalam jangka waktu 4 bulan mulai pada bulan Januari hingga April 2018. Metode yang dilakukan dalam pelaksanaan pengabdian masyarakat ini adalah 
Pendidikan masyarakat dimana dilakukannya pelatihan penenemuan suspect TB, pelaporan dengan GIS dan pemanfaatan media KIE.

\section{HASIL DAN PEMBAHASAN}

Gasurkes kota Semarang tahun 2018 sebagian besar melakukan penemuan kasus hanya dengan metode investigasi kontak. Belum ada gasurkes yang melakukan penemuan kasus TB dengan menggunakan pendekatan keluarga dan masyarakat. Pelatihan yang pernah diperoleh hanya pembekalan awal saat menjadi gasurkes. Diakhir pelatihan diperoleh bahwa gasurkes memahami populasi beresiko dan populasi kunci TB, macam metode penemuan kasus TB secara aktif yaitu investigasi kontak, penemuan aktif pada populasi kunci, penemuan di tempat khusus, penemuan di populasi beresiko, penemuan aktif berbasis keluarga dan masyarakat, penemuan aktif berkala dan skrinning massal. Hal ini menunjukkan bahwa terdapat peningkatan kemapuan Gasurkes untuk menemukan kasus TB baru.

Dalam pelaporan kasus penyakit menular Gasurkes telah menggunakan Sistem Informasi Geografis (SIG) berlisensi, dan hanya beberapa yang pernah menggunakan aplikasi SIG yaitu dengan Arcview. Penggunaan aplikasi SIG hanya untuk melihat jumlah sebaran sebaran kasus berdasarkan kelurahan dalam pelaporan. Gasurkes Kota Semarang sudah menggunakan GPS essential dalam menandai lokasi, namun belum mampu mengangkat titik lokasi ke dalam peta, karena belum memiliki peta Kota Semarang yang sesuai dengan titik koordinat. Seluruh gasurkes belum mengenal quantum GIS dan belum pernah menggunakan quantum GIS sebagai media pemetaan dan analisis kasus TB di masyarakat. Dalam pelatihan QuantumGIS diperoleh bahwa Gasurkes telah dapat men-download QGIS, menginstal QGIS, memulai proyek pembuatan peta, mengakses tool, mengambil info pada peta melaui status bar, melakukan georefrensi, melakukan digitasi poligon, line dan point, menginput data data atribut, mendisain style vektor, mengangkat lokasi tempat-tempat umum, mengangkat titik / memasukan titik hasil pengukuran lapangan, melakukan komposer pet, dan konversi peta. Semua gasurkes sudah dapat menggunakan Quantum-GIS untuk menggambar. Dalam pelatihan, materi yang diberikan tidak hanya penggunaan Qgis saja tetapi juga diberikan materi GPS essensial. Gasurkes sebelumnya belum mampu menggunakan GPS essensial dengan maksimal dan tepat. Setelah materi diberikan, hasil praktek langsung menunjukan seluruh Gasurkes telah mampu melakukan setting GPS dengan benar, menandai lokasi, serta mengekspor titik. Hal ini menunjukkan bahwa telah terdapat peningkatan kemampuan gasurkes untuk memanfaatkan teknologi sebagai sarana pelaporan kasus TB dalam hal ini adalah GIS. Serta peningkatan kemampuan gasurkes untuk memanfaatkan teknologi sebagai saran pemetaan kasus TB dalam hal ini adalah GIS.

Didalam pelatihan penggunaan KIE, Gasurkes diberikan materi mengenai Teknik komunikasi interpersonal dan pemilihan media yang tepat. Teknik membuat power point dan penyampaiannya. Teknik bagaimana berkomunikasi dengan penderita TB dimasyarakat sehingga tidak menimbulkan stigma. Dalam hal ini diperoleh bahwa terdapat peningkatan kemampuan gasurkes dalam pengembangan media KIE sebagai sarana mendukung penemuan kasus baru TB.

\section{KESIMPULAN}

Pelatihan gasurkes kota Semarang dalam rangka optimalisasi peran gasurkes dalam penanggulangan TB paru di kota Semarang telah mecapa target yaitu:

a. Peningkatan kemampuan tenaga surveilans kesehatan (Gasurkes) untuk menemukan kasus baru TB.

b. Peningkatan kemampuan gasurkes untuk memanfaatkan teknologi sebagai sarana pelaporan kasus TB dalam hal ini adalah GIS

c. Peningkatan kemampuan gasurkes untuk memanfaatkan teknologi sebagai saran pemetaan kasus TB dalam hal ini adalah GIS

d. Peningkatan kemampuan gasurkes dalam pengembangan media KIE sebagai sarana mendukung penemuan kasus baru TB 


\section{DAFTAR PUSTAKA}

1. Badan Pusat Statistik. Semarang Dalam Angka. Semarang. 2017. https://semarangkota.bps.go.id/

2. Dinas Kesehatan Kota Semarang. Profil Kesehatan Kota Semarang. Jawa Tengah. 2017

3. Kementrian Kesehatan RI. Buku Pedoman Program penangulangan TB. Jakarta. 2010

4. Soontornpipit, P., Viwatwongkasem, C., \& Taratep, C. (2016). Development of the electronic surveillance monitoring system on web applications. Procedia - Procedia Computer Science, 86(March), 244-247. https://doi.org/10.1016/j.procs.2016.05.110

5. Tanser, Frank C, and David le Sueur. "The Application of Geographical Information Systems to Important Public Health Problems in Africa." International Journal of Health Geographics 1 (2002): 4. PMC. Web. 14 Dec. 2017.

6. Wilkinson D, Pillay M, Crump J, Lombard C, Davies GR, Sturm AW. Molecular epidemiology and transmission dynamics of Mycobacterium tuberculosis in rural Africa. Trop Med Int Health. 1997;2:747-53. doi: 10.1046/j.1365-3156.1997.d01-386.x. [PubMed] [Cross Ref] 